\title{
Pathogenic fungi in the work environment of organic and conventional farmers
}

\author{
Wioletta Żukiewicz-Sobczak ${ }^{1,2}$, Grażyna Cholewa', Ewelina Krasowska ${ }^{1}$, Jacek Zwoliński', Paweł Sobczak \\ Kazimierz Zawiślak ${ }^{3}$, Jolanta Chmielewska-Badora' ${ }^{1}$, Jacek Piątek ${ }^{1}$, Andrzej Wojtyła ${ }^{2}$
}

1Department of Allergology and Environmental Hazards, Institute of Rural Health, Lublin, Poland Head: Wioletta Żukiewicz-Sobczak MD, PhD

2Department of Promotion, Food and Nutrition, Institute of Rural Health, Lublin, Poland

Head: Andrzej Wojtyła MD, PhD

${ }^{3}$ Department of Food Engineering and Machines, University of Life Sciences in Lublin, Poland

Head: Prof. Kazimierz Zawiślak

\begin{abstract}
Recent research conducted at the Institute of Rural Health indicated the harmfulness of organic dusts present in the environments of agricultural producers. Due to the high concentration of biological agents contained in dust grains, derived from conventional and organic cropping systems, there is a real risk of developing respiratory diseases in people doing agricultural work. Conventional and organic cropping systems differ significantly in terms of fertilization method and plant protection. Such differences may also influence the composition of biological agents in grain dust, which can cause various health effects in humans. No assessment has been carried out in farms with different systems of farming. Ambiguous statements on existing health risks in people doing agricultural work on conventional and organic farms prompted the Department of Allergy and Environmental Hazards, Institute of Rural Health in Lublin, to perform mycological tests and assess the degree of contamination with fungi pathogenic for humans in grain dust and grain from organic and conventional farms. A literature review and research conducted at the Institute of Rural Medicine show that the problem of occupational exposure to the presence of molds and mycotoxins in grains and grain dusts and their possible role in the development of pathological changes of the respiratory system is very important from the standpoint of hygiene and occupational medicine, and still requires further studies.
\end{abstract}

Key words: molds, conventional crops, organic farming.

\section{Introduction}

High concentrations of biological agents contained in grain dust derived from conventional and organic cropping systems could pose a real danger of developing respiratory diseases in people doing agricultural work. Conventional and organic cropping systems significantly differ in terms of method of fertilization and plant protection, and this may influence the biological agents contained in grain dust which can cause various health effects in humans. The views concerning the impact on health of the two production systems are still divided, not only because of the quality of raw materials produced, but also because of the health hazard for people working with crops. One theory assumes that a different method of fer- tilization, characterized by organic farming, causes changes in the metabolism of plants. Greater amounts of secondary metabolites cope better with the threats in the form of fungal diseases or insects. This would mean that pathogenic fungi should be less frequent in products derived from organic production systems. On the other hand, in organic farming conventional antifungal preparations are not applied. The ecological system prohibits chemical treatment of raw materials, and seed quality standards in organic farming provide detailed features of the grain [1]. In addition, there are also specific plant protection measures which are essential in conventional agriculture in the fight against weeds and pests. From this point of view a greater number of weeds and crop dam- 
age by pests can contribute to greater infestation by pathogenic fungi. Ambiguity on this subject prompted the Department of Allergology and Environmental Hazards from the Institute of Rural Health in Lublin to perform mycological tests and assess the population of grains and organic dusts from farms with conventional and ecological profiles of fungi pathogenic for humans.

Data taken from the reports of the Agricultural and Food Quality Inspection show that in recent years, organic farming in Poland has been growing rapidly, and organic agricultural producers constitute the majority of agricultural producers. Data obtained from the Central Statistical Office, from the years 2009-2010, indicate that organic agricultural producers accounted for approximately $98 \%$ of all producers. In 2010 we saw an increase in the number of organic producers in 15 Polish provinces, with the exception of the Małopolska province. In the structure of organic agricultural land derived from 2010, meadows and pastures had the largest share (42.3\%), followed by crops to feed (20.6\% of agricultural land), then corn (19.6\%) and other crops (17.5\%) [2]. One of the oldest and most widely grown cereals in the world is wheat. According to literature sources the area under wheat in Poland in 2008 was 2277954 ha [3]. Wheat, like other grains, can be infected at all stages of its development by fungi, which in turn can reduce grain quality and can cause significant losses in yield [4-6]. One of the grains belonging to plants less susceptible to fungal diseases is a mutant of wheat and rye, triticale [7]. Triticale cultivation has many advantages: it is more resistant to diseases of wheat and rye (including complete resistance to smut and rust caused by fungi of the genus Basidiomycetes), to lodging, has good winter hardiness, has lower soil requirements than wheat, and greater resistance to weeds and drought [8]. Numerous studies indicate that the grain ripened in spikes or stored in low humidity conditions, subjected to microdamage resulting from the technique of harvesting and the threshing machine, may be a substrate for the growth of fungi [9]. The composition of fungi present in the grain depends on the conditions prevailing during the growing season (e.g., weather conditions, the method of cultivation, application of chemical fertilizers and pesticides) $[1,10]$. Many studies confirm that climatic conditions have a significant impact on the development of various plant pathogens. The species of the genus Fusarium prefer high humidity persisting longer than $24 \mathrm{~h}$ and air temperatures reaching above $20^{\circ} \mathrm{C}$ [11-16]. Some of the research conducted at the Institute of Rural Health in 10 samples of wheat and 10 samples of settled dust, collected from farms that carry out threshing using a combine harvester, showed the presence in grain of wheat fungal species Alternaria alternata, Geotrichum candidum, Aspergillus fumigatus, Monilia candida and white yeasts, in samples of settled dust fungi of the genus Penicillium and species Alternaria alter- nata, Rhodotorula rubra, Oidiodendron flavum, Monilia linicola geophila and Cladosporium linicola [17].

The population of professionals potentially exposed to biological agents contained in the grain dust are agricultural workers (including employees of certain sectors of the agro-food industry) $[18,19]$. In many studies the authors have shown that inhalation of organic dust contaminated with mold spores may cause allergic respiratory diseases. The literature shows that the components of organic dust can cause asthma, allergic alveolitis, organic dust toxic syndrome (ODTS), byssinosis, chronic bronchitis, allergic rhinitis, mucous membrane irritation, sick building syndrome (SBS), chronic fatigue syndrome (CFS) and certain infectious diseases and cancer $[17,18,20]$. Very high exposure in the agricultural work environment occurs during grain harvesting and threshing, feed administration, rapeseed threshing, herbs cleaning, tobacco cultivation, collecting hay from the fields, flax turbination and pig and cattle breeding [17, 21-24]. Previous studies conducted at the Institute of Rural Health on health risks for farmers in conventional farms showed that molds belonging to different genera and species, such as Penicillium spp., Mucor spp., Alternaria alternata, Cladosporium fulvum, Cladosporium herbarum, Aspergillus fumigatus, Aspergillus niger, and Aspergillus candidus may be etiologic factors of allergic and immunotoxic diseases. In the literature there are few data on levels of pathogenic fungi in the work environment of farmers. There is no information about the health hazards of agricultural producers in the Polish organic farms. Most research on organic farms, from the last decade, mainly focused on the phytopathological aspect. To date there are no specified levels of molds and their metabolites in organic dusts from organic farms.

\section{Aim}

The aim of research conducted at the Institute of Rural Health in 2010-2011 in Lublin, Poland was to compare the existing occupational risk for agricultural producers due to the presence of mold in the grain and grain dust on conventional and ecological farms. Comparison of the two tillage systems helps to determine whether a particular system has an effect on colonization of wheat and triticale by filamentous fungi and yeasts, which in turn may be a potential cause of symptoms in people exposed to inhalation of grain dust.

\section{Material and methods}

As part of the project by the Department of Allergology and Environmental Hazards from the Institute of Rural Health in Lublin in 2010, wheat grain and wheat dust formed during the threshing of wheat were sampled, while in 2011 triticale samples (grain and dust) formed during the threshing of grown triticale were collected in 
conventional and organic farms from the Lublin area. The concentration and composition of species of fungi on potato agar (PDA) in the collected samples of wheat and triticale were determined. The collected samples of specified concentration and species composition of filamentous fungi, using the dilution plating method consisting in the execution of logarithmic dilutions of the sample (from $10^{2}-10^{8}$ ), were then plated onto the substrate with each dilution. The plates were incubated in a thermostat at $30^{\circ} \mathrm{C}$ for $72 \mathrm{~h}$ then at room temperature for $72 \mathrm{~h}$, after which the specified concentration of fungi in CFU/g was determined. In the final stage the fungal species were identified using macroscopic and microscopic methods (size, shape, size and color of the colony, shape, color and surface of conidia, length and color of conidiophores, the number of sterigma rows) based on mycological keys, and finally the species composition of flora was determined in percentages and images were made with a microscope and camera.

\section{Results}

In the samples of wheat grain and dust collected from organic farming significant levels of fungi were found. In the dust of wheat they were present in the range of $25 \times 10^{5}-33 \times 10^{5} \mathrm{CFU} / \mathrm{g}$, and in wheat grain within the limits of $8.5 \times 10^{3}-12 \times 10^{3} \mathrm{CFU} / \mathrm{g}$. It should be noted that higher concentrations of fungi were found in the dust than in grain. In the samples of wheat grain collected from organic farming were Aspergillus flavus, Cladosporium sp., Aureobasidium sp., Ulocladium sp., Cladosporium macrocarpum, Fusarium sp., Penicillium sp.,

Table 1. Molds and yeasts identified in the grain and dust of wheat taken from conventional and organic crops from the province of Lublin in 2010, isolated on PDA medium

\begin{tabular}{|c|c|c|c|c|}
\hline \multirow[t]{3}{*}{ Fungi and yeasts } & \multicolumn{4}{|c|}{ Wheat 2010} \\
\hline & \multicolumn{2}{|c|}{ Wheat grain } & \multicolumn{2}{|c|}{ Wheat dust } \\
\hline & Organic farming [\%] & Conventional crops [\%] & Organic farming [\%] & Conventional crops [\%] \\
\hline Acremoniella atra & 0.00 & 0.85 & 0.00 & 0.00 \\
\hline Alternaria alternata & 0.00 & 0.85 & 0.00 & 0.00 \\
\hline Alternaria sp. & 0.00 & 0.00 & 1.19 & 0.87 \\
\hline Aspergillus flavus & 23.42 & 0.00 & 0.00 & 7.23 \\
\hline Aureobasidium sp. & 16.22 & 0.00 & 0.00 & 0.00 \\
\hline Cladosporium herbarum & 0.00 & 6.78 & 7.94 & 5.49 \\
\hline Cladosporium macrocarpum & 6.31 & 7.63 & 9.52 & 8.67 \\
\hline Cladosporium sp. & 22.52 & 38.14 & 32.54 & 33.24 \\
\hline Cladosporium sphaerospermum & 1.80 & 4.24 & 0.00 & 0.00 \\
\hline Yeasts & 0.90 & 19.49 & 0.00 & 8.67 \\
\hline Fusarium oxysporum & 0.00 & 0.85 & 0.00 & 0.00 \\
\hline Fusarium sp. & 6.31 & 3.39 & 18.25 & 9.54 \\
\hline Gonatobotrys sp. & 0.00 & 0.00 & 14.29 & 12.72 \\
\hline Mucor hiemalis & 0.00 & 3.39 & 0.79 & 0.00 \\
\hline Mucor racemosus & 0.00 & 2.54 & 0.00 & 0.00 \\
\hline Mucor sp. & 0.00 & 0.00 & 1.59 & 2.02 \\
\hline Paeciliomyces variotii & 0.00 & 1.69 & 0.00 & 0.00 \\
\hline Penicillium citrinum & 0.00 & 3.39 & 0.00 & 0.00 \\
\hline Penicillium expansum & 2.70 & 0.00 & 2.38 & 2.89 \\
\hline Penicillium sp. & 4.50 & 0.00 & 7.14 & 5.78 \\
\hline Ulocladium sp. & 11.71 & 1.69 & 4.37 & 2.89 \\
\hline Ulocladium chartarum & 3.60 & 5.08 & 0.00 & 0.00 \\
\hline$\Sigma$ & 100.00 & 100.00 & 100.00 & 100.00 \\
\hline
\end{tabular}


Table 2. Molds and yeasts identified in triticale grain and dust collected from conventional and organic crops from the province of Lublin in 2011, isolated on PDA medium

\begin{tabular}{|c|c|c|c|c|}
\hline \multirow[t]{3}{*}{ Fungi and yeasts } & \multicolumn{4}{|c|}{ Triticale 2011} \\
\hline & \multicolumn{2}{|c|}{ Triticale grain } & \multicolumn{2}{|c|}{ Triticale dust } \\
\hline & Organic farming [\%] & Conventional crops [\%] & Organic farming [\%] & Conventional crops [\%] \\
\hline Absidia sp. & 5.41 & 0.00 & 0.00 & 0.00 \\
\hline Alternaria alternata & 2.70 & 4.11 & 4.32 & 3.33 \\
\hline Aspergillus fumigatus & 0.00 & 0.00 & 0.00 & 0.83 \\
\hline Aspergillus sp. & 2.70 & 0.00 & 0.00 & 0.00 \\
\hline Aureobasidium sp. & 0.00 & 0.00 & 2.43 & 38.04 \\
\hline Cladosporium herbarum & 2.70 & 0.68 & 0.00 & 0.00 \\
\hline Cladosporium macrocarpum & 32.43 & 2.74 & 15.95 & 0.00 \\
\hline Cladosporium sp. & 2.70 & 0.68 & 7.84 & 1.66 \\
\hline Yeasts & 45.95 & 67.12 & 4.59 & 11.23 \\
\hline Fusarium culmorum & 0.00 & 0.00 & 0.27 & 0.00 \\
\hline Fusarium sp. & 5.41 & 4.11 & 37.30 & 21.83 \\
\hline Gonatobotrys sp. & 0.00 & 2.05 & 3.24 & 8.11 \\
\hline Penicillium sp. & 0.00 & 6.16 & 1.08 & 1.25 \\
\hline Rhizopus sp. & 0.00 & 0.00 & 0.81 & 0.00 \\
\hline Stachybotrys chartarum & 0.00 & 2.74 & 0.00 & 0.00 \\
\hline Trichophyton sp. & 0.00 & 0.00 & 0.54 & 0.00 \\
\hline Ulocladium sp. & 0.00 & 9.59 & 21.62 & 13.72 \\
\hline$\Sigma$ & 100.00 & 100.00 & 100.00 & 100.00 \\
\hline
\end{tabular}

Ulocladium chartarum, Penicillium expansum, Cladosporium sphaerospermum and yeasts. In the samples of wheat grain and dust collected from conventional crops fungi were also found at high levels, in the dust of wheat within the range of $20.5 \times 10^{5}-40 \times 10^{5} \mathrm{CFU} / \mathrm{g}$, and in the wheat grain $7.5 \times 10^{3}-20.5 \times 10^{3} \mathrm{CFU} / \mathrm{g}$. In the samples of wheat grain collected from conventional crops were Cladosporium sp., yeasts, Cladosporium macrocarpum, Cladosporium herbarum, Ulocladium chartarum, Cladosporium sphaerospermum, Fusarium sp., Mucor hiemalis, Penicillium citrinum, Mucor racemosus, Pae- cilomyces variotii, Ulocladium sp., Acremoniella atra, Alternaria alternata, Fusarium oxysporum. In the samples of wheat dust from organic farming the following molds were found: Cladosporium sp., Fusarium sp., Gonatobotrys sp., Cladosporium macrocarpum, Cladosporium herbarum, Penicillium sp., Ulocladium sp., Penicillium expansum, Mucor sp., Alternaria sp., Mucor hiemalis. In the samples of wheat dust from conventional crops, the following fungi were found: Cladosporium sp., Gonatobotrys sp., Fusarium sp., Cladosporium macrocarpum, yeasts, Aspergillus flavus, Penicillium sp., Cladosporium herbarum, Penicilli-

Table 3. The concentration of fungi in wheat grain and wheat dust, samples collected from conventional and organic crops from the province of Lublin in 2010, isolated on PDA medium

\begin{tabular}{lcccr}
\hline $\begin{array}{l}\text { Number } \\
\text { of sample }\end{array}$ & $\begin{array}{c}\text { Wheat grain - } \\
\text { conventional crops }\end{array}$ & $\begin{array}{c}\text { Wheat grain - } \\
\text { organic farming }\end{array}$ & $\begin{array}{c}\text { Number } \\
\text { of sample }\end{array}$ & $\begin{array}{c}\text { Wheat dust - } \\
\text { conventional crops } \\
\text { organic farming }\end{array}$ \\
\hline 1 & $8.5 \times 10^{3}$ & $12 \times 10^{3}$ & 5 & $20.5 \times 10^{5}$ \\
\hline 2 & $7.5 \times 10^{3}$ & $8.5 \times 10^{3}$ & 6 & $38 \times 10^{5}$ \\
\hline 3 & $20.5 \times 10^{3}$ & $9 \times 10^{3}$ & 7 & $27 \times 10^{5}$ \\
\hline 4 & $10 \times 10^{3}$ & $9 \times 10^{3}$ & 8 & $40 \times 10^{5}$ \\
\hline
\end{tabular}


W. Żukiewicz-Sobczak, G. Cholewa, E. Krasowska, J. Zwoliński, J. Chmielewska-Badora, J. Piątek, P. Sobczak, K. Zawiślak, A. Wojtyła

Table 4. The concentration of fungi in triticale grain and triticale dust, samples collected from conventional and organic crops from the province of Lublin in 2011, isolated on PDA medium

\begin{tabular}{lccccc}
\hline $\begin{array}{l}\text { Number } \\
\text { of sample }\end{array}$ & $\begin{array}{c}\text { Triticale grain - } \\
\text { organic farming }\end{array}$ & $\begin{array}{c}\text { Triticale dust }- \\
\text { organic farming }\end{array}$ & $\begin{array}{c}\text { Number } \\
\text { of sample }\end{array}$ & $\begin{array}{c}\text { Triticale grain - } \\
\text { conventional crops }\end{array}$ & $\begin{array}{c}\text { Triticale dust - } \\
\text { conventional crops }\end{array}$ \\
\hline 1 & $5.5 \times 10^{3}$ & $19 \times 10^{4}$ & 6 & $4 \times 10^{3}$ & $33 \times 10^{4}$ \\
\hline 2 & $0.5 \times 10^{3}$ & $20.5 \times 10^{4}$ & 7 & $6.5 \times 10^{3}$ & $47 \times 10^{4}$ \\
\hline 3 & $1 \times 10^{3}$ & $38 \times 10^{4}$ & 8 & $7 \times 10^{3}$ & $32 \times 10^{4}$ \\
\hline 4 & $1 \times 10^{3}$ & $21 \times 10^{4}$ & 9 & $1.5 \times 10^{3}$ & $36 \times 10^{4}$ \\
\hline 5 & 0 & $37.5 \times 10^{4}$ & 10 & $5.5 \times 10^{3}$ & $6.6 \times 10^{4}$ \\
\hline
\end{tabular}

um expansum, Ulocladium sp., Mucor sp., Alternaria sp. In the samples of triticale grain and dust samples from organic farming were the following concentrations of fungi: the dust from triticale $-19 \times 10^{4}-38 \times 10^{4} \mathrm{CFU} / \mathrm{g}$, in triticale grain $-0-5.5 \times 10^{3} \mathrm{CFU} / \mathrm{g}$. In the triticale grain samples from organic farming, the following fungi were identified: yeasts, Cladosporium macrocarpum, Absidia sp., Fusarium sp., Alternaria alternata, Aspergillus sp., Cladosporium herbarum, Cladosporium sp. In the samples of triticale grain from conventional farming, the following fungi were present: yeasts, Ulocladium sp., Penicillium sp., Alternaria alternata, Fusarium sp., Cladosporium macrocarpum, Stachybotrys chartarum, Gonatobotrys sp., Cladosporium herbarum, Cladosporium sp. In the samples of triticale grain and dust collected from conventional crops the following concentrations of fungi were determined: the dust from triticale, $6.6 \times 10^{4}-47 \times 10^{4} \mathrm{CFU} / \mathrm{g}$; in triticale grain, around $1.5 \times 10^{3}-7 \times 10^{3} \mathrm{CFU} / \mathrm{g}$. The concentration of fungi in the collected samples of organic farms was lower than in samples from conventional farms, which may indicate a higher efficiency of organic farming in terms of contamination of mold fungi. In tests of triticale dust from organic crops the following fungi were identified: Fusarium sp., Ulocladium sp., Cladosporium macrocarpum, Cladosporium sp., yeasts, Alternaria alternata, Gonatobotrys sp., Aureobasidium sp., Penicillium sp., Rhizopus sp., Trichophyton sp., Fusarium culmorum. In the samples of triticale dust from conventional crops, the following molds were found: Aureobasidium sp., Fusarium sp., Ulocladium sp., yeasts, Gonatobotrys sp., Alternaria alternata, Cladosporium sp., Penicillium sp., Aspergillus fumigatus. The isolated fungi, as well as the dominance of species including Alternaria alternata, are known and are confirmed by the literature of this field $[25,26]$.

These results are consistent with the objectives of the research project, i.e., pathogenic fungi are present in smaller amounts of products derived from organic production systems. Despite the fact that organic farming does not apply antifungal preparations and typical characteristics of plant protection measures, which are the basis in conventional agriculture of the fight against weeds and pests, it is appropriately matched to the type of cereal crops to better cope with threats such as fungi. It should be noted that the meteorological conditions during the summer in the years 2010-2011 were extremely wet, which had a significant impact on biodiversity and concentration of the identified species. The high degree of grain infestation was associated with the weather conditions prevailing during the growing season. High levels of precipitation and moderate temperatures during the summer months (June-August) constitute a favorable environment for the development of fungi infecting grain [26]. The entire test results revealed a significant health hazard for agricultural producers, due to the presence of allergenic and toxinogenic molds occurring in crops of wheat and triticale. They represent a potential health hazard for farmers exposed to inhalation of dust during operation and thus indicate a substantial degree of occupational exposure in this occupational group.

\section{Discussion}

The research indicates considerable contamination of grain samples and grain dust samples of wheat and triticale with molds. The scientific literature widely describes exposure to mycotoxins entering the body by ingestion but inhalation exposure - most relevant for hygiene and occupational medicine - is still poorly understood [9]. From trials with conventional and organic crops of wheat, the most frequently isolated were fungi from the genera Cladosporium and Fusarium and also yeasts. In the case of triticale, the most numerous were fungi of the genera Fusarium, Cladosporium, Alternaria, Ulocladium and also yeasts. Fusarium spp. produce many metabolites and the most important group of metabolites among zootoxins are trichothecenes, which can cause numerous human and animal intoxications [27]. Fungi of the genus Cladosporium very rarely cause opportunistic fungal infections, but from the standpoint of allergy are a common allergen [28]. Cladosporium and Alternaria are responsible for inhalant allergies (oculorhinitis, mold asthma). They can also cause allergic alveolitis: Alternaria - "woodworker's lung", Cladosporium - 
"tobacco worker's lung". Also important for allergy are yeast, Aspergillus and Penicillium [29]. Ulocladium sp. rarely causes disease in humans. Among the isolated fungi Aspergillus and Trichophyton occurred less frequently. According to the classification, taking into account biosafety of fungi potentially pathogenic for humans and animals, fungi have been included in the class of BSL-2 because they are not neutral to human health [30]. In this group are also fungi of the genera Fusarium and Absidia. Rhizopus sp. and yeasts can have first or second degree of risk to health [28]. The literature shows that diseases caused by the harmful effects of mycotoxins - mycotoxicoses - have been known for many years. Inhaled mycotoxins with grain dust arising during agricultural work are a potential occupational hazard for farmers. Particularly important are the trichothecenes, produced by different species of fungi of the genus Fusarium, and ochratoxin, produced by fungi of the genera Aspergillus and Penicillium [17, 31]. Because of their low volatility, mycotoxins rarely can be secreted directly into the air or may be present in airborne particles or hyphal fragments with a diameter allowing them to reach the alveoli [32]. In the situation when the grain dust has several mycotoxins, their effect may accumulate and cause disease symptoms in the form of "acute episodes of lung" and other symptoms such as burning eyes, shortness of breath, chest pain, fever, dry cough and malaise [17, 31, 33, 34]. High risk of exposure to inhaled mycotoxins occurs due to storage of grain insufficiently desiccated, high temperatures, and lack of air circulation in the silo. Health risk is also associated with emptying silos (or other grain storage areas), and further marketing or processing of grain (trade, milling, etc.) [9]. The frequent occurrence of T-2 toxin - an inhibitor of protein synthesis that affects the immune system - is found in different varieties of winter and spring cereals. The highest concentration of this mycotoxin was observed in organic cereals such as wheat, rye and triticale. Zearalenone, another dangerous mycotoxin, according to the literature appeared widely in organic cereals such as rye, barley and oats $[33,35]$. Consuming food or feeding animals with mycotoxin contaminated feed can cause various diseases in humans and animals referred to as mycotoxicoses. They represent a direct threat to humans and warm-blooded animals. The danger arising from the possible production of toxic fungi metabolites is included in the assumptions of the national defense. Mycotoxins such as aflatoxin and T-2 toxin are recognized by the National Security Bureau as potential biological weapons [36].

\section{Conclusions}

Based on the survey it was found that the concentration of fungi in the collected samples from ecological farms was lower than in samples taken from conventional farms. In samples of grains and grain dust of wheat and triticale, higher concentrations of fungi occurred in the dust than in grains. This indicates a high degree of risk to the health of people working on growing, harvesting and storing grain. The isolated species of fungi also demonstrated the direct exposure of people engaged in agricultural work to the effects of metabolites produced by these fungi. Although not all aspects of the impact of mycotoxins on humans by inhalation are known, there is reason to believe that long-term inhalation of even small doses of these compounds not only can cause mycotoxicosis, but may also involve the risk of cancer [17, 31, 37-42]. The review of the literature and our own investigations show that the problem of occupational exposure to the presence of molds and mycotoxins in grain and grain dust, and their role in the development of pathological changes of the respiratory system, is very important and still needs further investigation [9, 43-45].

\section{References}

1. Girsch L, Weinhappel M. Specific seed health standards for organic cereal seed. Proc. of the First world Conference on Organic Seed, July 5-7, FAO, 2004 Rome, Italy: 79-83.

2. Zdrojewska I. Report on the status of organic farming in Poland in the years 2009-2010. Agricultural and Food Quality Inspection. IJHARS. Warsaw 2011 [Polish].

3. Central Statistical Office. Regional Data Bank. Data for 20072008 [Polish].

4. Korbas M. Diseases of the grain, opportunities and prospects for eradication [Polish]. Prog Plant Protection/Post Ochr Roślin 2004; 44: 147-54.

5. Weber R. Risks and ways of reducing wheat fusarium diseases [Polish]. Post Nauk Rol 2007; 2: 19-31.

6. Suchorzyńska M, Misiewicz A. Mycotoxic phytopathogenic fungi of the genus Fusarium and detection of PCR techniques [Polish]. Post Mikrobiol 2009; 48: 221-30.

7. Boligłowa E, Klima K. Health status of spring triticale grown in organic and conventional system [Polish]. Progress in Plant Protection 2010; 50: 615-9.

8. Woś H, Banaszak Z, Mikulski W. Triticale: yesterday, today and tomorrow [Polish]. Wieś Jutra 2008; 4: 31-3.

9. Soroka PM, Cyprowski M, Szadkowska-Stańczyk I. Occupational exposure to mycotoxins in various branches of industry. Med Pr 2008; 59: 333-45.

10. Szwajkowska-Michalek L, Stuper K, Lakomy P, et al. Contents of microscopic fungi in dusts coming from cereal analysis laboratories. Ann Agric Environ Med 2010; 17: 101-6

11. Brennan JM, Egan D, Cooke BM, Doohan FM. Effect of temperature on head blight of wheat caused by Fusarium culmorum and F. graminearum. Plant Pathol 2005; 54: 156-60.

12. Brennan JM, Fagan B, van Maanen A, et al. Studies on in vitro growth and pathogenicity of European Fusarium Fungi. Eur J Plant Pathol 2003; 109: 577-87.

13. Jaczewska-Kalicka A. The occurrence of disease and crop losses of winter wheat with particular reference to the impact of climate [Polish]. Prog Plant Protection 2001; 41: 607-16.

14. Matusinsky P, Mikolasova R, Klem K, Spitzer T. Eyespot infection risks on wheat with respect to climatic conditions and soil management. J Plant Pathol 2009; 91: 93-101.

15. Suproniene S, Justesen A, Nicolaisen M, et al. Distribution of trichothecene and zearalenone producing Fusarium spe- 
cies in grain of different cereal species and cultivars grown under organic farming conditions in Lithuania. Ann Agric Environ Med 2010; 17: 79-86

16. Sutton JC. Epidemiology of wheat head blight and maize ear rot caused by Fusarium graminearum. Can J Plant Pathol 1982; 4: 195-209.

17. Krysińska-Traczyk E, Perkowski J, Kostecki M, et al. Filamentous fungi and mycotoxins as potential occupational risk factors among farmers harvesting various crops [Polish]. Med Pr 2003; 54: 133-8.

18. Dutkiewicz J, Górny RL. Biologic factors hazardous to health classification and criteria of exposure assessment [Polish] Med Pr 2002; 53: 29-39.

19. Broding HC, Frank P, Hoffmeyer F, Bunger J. Course of occupational asthma depending on the duration of workplace exposure to allergens - a retrospective cohort study in bakers and farmers. Ann Agric Environ Med 2011; 18: 35-40.

20. Jahnz-Rozyk K, Targowski T, Owczarek W, et al. Effects of allergic diseases, concomitant with allergic rhinitis, on the clinical efficacy and costs of allergen-specific immunotherapy in Poland. Postep Derm Alergol 2011; 28: 378-81.

21. Krysińska-Traczyk E. Mold fungi as an etiologic factor of occupational diseases occurring in the agricultural and forestry work environment [Polish]. Med Wiej 1994; 29: 108-14.

22. Krysińska-Traczyk E. Microflora of the farming work environment as an occupational risk factor [Polish]. Med Pr 2000 51: 351-5.

23. Krysińska-Traczyk E, Skórska C, Prażmo Z, et al. Bio-aerosols as potential health hazards for farmers working in the grain threshing [Polish]. Med Ogólna 1999; 5: 301-6.

24. Krysińska-Traczyk E, Dutkiewicz J, Skórska C, et al. Occupational exposure to individual farmers on bio-aerosols occurring in the dust with thyme [Polish]. Med Ogólna 1999; 5; 186-93.

25. Nowicki B, Zamorski C, Schollenberger M. Pathogenic fungi colonizing grains of triticale. Acta Agrobot 1996; 49: 107-14

26. Kwiatkowski J, Wachowska U. Fungal communities of different generations of triticale grain in 1993-1994. Acta Agrobot 2005; 58: 135-42.

27. Kwaśna H, Chełkowski J, Zajkowski P. Fusarium (Sierpik) in the series: Fungi (Mycota) [Polish]. Vol. XXII - Institute of Botany Polish Academy of Sciences, Kraków 1991.

28. Krzyściak P, Skóra M, Macura AB. Atlas of human pathogenic fungi. Med Pharm, Wrocław 2010.

29. Baran E. Draft of medical mycology [Polish]. Wrocław 1998.

30. Nabrdalik M. Filamentous fungi in buildings. Ecol Chem Eng 2007; 14: 489-96.

31. Hintikka EL, Nikulin M. Airborne mycotoxins in agricultural and indoor environments. Indoor Air 1998; 4: 66-70.

32. Sorenson WG. Fungal spores: hazardous to health. Environ Health Perspect 1999; 107: 469-72.

33. Cudowska B, Marcinkiewicz S, Kaczmarski M. Sensitization to cereal allergens in children with atopic dermatitis. Postep Derm Alergol 2011; 28: 181-6.

34. Perry LP, Iwata M, Tazelaar HD, et al. Pulmonary mycotoxicosis: a clinicopathologic study of three cases. Med Pathol 1998; 2: 432-6.

35. Solarska E, Mazurkiewicz J, Pałka A, Potocka E. Determining the occurrence of mycotoxins in different varieties of winter and spring cereals grown organically. Ministry of Agriculture and Rural Development, Summary of results of research on organic farming carried out in 2008 [Polish]. Warsaw 2009; 245-52.

36. Korbas M, Horoszkiewicz-Janka J. Importance and the potential to reduce harmful fungal metabolites [Polish]. Prog Plant Protection/Post Ochr Roślin 2007; 47: 141-7.
37. Perry LP, Iwata M, Tazelaar HD, et al. Pulmonary mycotoxicosis: a clinicopathologic study of three cases. Med Pathol 1998; 2: 432-6.

38. Munoz Rodriguez AF, Palacios I, Molina R. Influence of meteorological parameters in hourly patterns of grass (Poaceae) pollen concentrations. Ann Agric Environ Med 2010; 17: 87-100.

39. Karakis GP, Sin B, Tutkak H, et al. Genetic aspect of venom allergy: association with HLA class I and class II antigens. Ann Agric Environ Med 2010; 17: 119-23.

40. Perez-Badia R, Rapp A, Morales C, et al. Pollen spectrum and risk of pollen allergy in central Spain. Ann Agric Environ Med 2010; 17: 139-51.

41. Pérez-Badia R, Vaquero C, Sardinero S, et al. Intradiurnal variations of allergenic tree pollen in the atmosphere of Toledo (central Spain). Ann Agric Environ Med 2010; 17: 269-75.

42. Brinchmann BC, Bayat M, Brogger T, et al. A possible role of chitin in the pathogenesis of asthma and allergy. Ann Agric Environ Med 2011; 18: 7-12.

43. Żukiewicz-Sobczak W, Cholewa G. Fungi and substances produced by them as a threat to the health of agricultural workers and animal breeders [Polish]. Institute of Rural Health in Lublin 2011; 96-102.

44. Jakubowicz J, Jakubowicz O, Żaba C, et al. Nowe regulacje prawne dotyczące chorób zawodowych. Postep Derm Alergol 2010; 27: 122-5.

45. Lemieszek M, Chilosi M, Golec M, et al. Mouse model of hypersensitivity pneumonitis after inhalation exposure to different microbial antigens associated with organic dusts. Ann Agric Environ Med 2011; 18: 159-68. 